\title{
Red Wine Prevents Brain Oxidative Stress and Nephropathy in Streptozotocin-induced Diabetic Rats
}

\author{
Pedro Montilla ${ }^{\dagger, *}$, Montserrat Barcos ${ }^{\ddagger}$, Maria C. Muñoz ${ }^{\dagger}$ Inmaculada Bujalance ${ }^{\dagger}$, \\ Juan R. Muñoz-Castañeda ${ }^{\S}$ and Isaac Tunez \\ 'Departamento de Bioquimica y Biologia Molecular, Facultad de Medicina, Universidad de Cordoba, Spain \\ Servicio de Analisis Clinicos, Hospital Universitario Reina Sofia, Cordoba, Spain \\ ${ }^{\S}$ Unidad de Higado, Departamento de Patologia, Hospital Universitario Reina Sofia, Cordoba, Spain
}

Received 8 April 2005, Accepted 18 May 2005

\begin{abstract}
We have studied the effects of red wine on brain oxidative stress and nephropathy in streptozotocin (STZ)-induced diabetic rats. Diabetes was induced in Wistar rats with a single intraperitonally injection of STZ $(50 \mathrm{mg} / \mathrm{kg})$. Two weeks before and four weeks after injection, red wine was given orally in both normal and diabetic rats. Blood samples were taken from the neck vascular trunk in order to determine the glucose, triglycerides, total cholesterol, HDL-cholesterol (HDL-c), atherogenic index (AI), total protein, blood urea nitrogen (BUN), creatinine, insulin, lipid peroxidation products, reduced glutathione (GSH) and superoxide dismutase (SOD) and glutathione peroxidase (GSH-Px) activities. As well, we estimated the lipid peroxidtion, GSH and SOD, GSH-Px and catalase activities in brain and renal homogenates, and the excretion of albumin, proteins and glucose in urine over 24 $h$ period. The administration of STZ caused significant increases in levels of glycosuria, proteinuria, albuminuria, glycemia, total cholesterol and AI, as well as in lipid peroxidation products in the brain, plasma and kidney, whereas it decreased the GSH content and SOD, GSH-Px and catalase activities. Treatment with red wine significantly prevented the changes induced by STZ. These data suggested that red wine has a protective effect against brain oxidative stress, diabetic nephropathy and diabetes induced by STZ, as well as it protects against hypercholesterolemia and atherogenic risk.
\end{abstract}

Keywords: Diabetes, Nephropathy, Oxidative stress, Red wine, Streptozotocin

\footnotetext{
*To whom correspondence should be addressed.

Tel: 349572182 68; Fax: 34957218229

E-mail:bb1molop@uco.es
}

\section{Introduction}

Diabetes mellitus is a common but serious metabolic disorder associated with many functional and structural complications (McCall, 1992; Gispen and Biessels, 2000). This disorder is associated with an increased production of reactive oxygen species (ROS) in both humans and animals. Experimental evidence has supported that ROS play a role in both pathogenesis and numerous pathophysiological mechanisms that trigger diabetic complications, primarily categorized into macroangiopathy and microangiopathy, the latter of witch includes retinopathy, nephropathy, neuropathy, and microvascular damage to the cerebral artery (Hyslop et al., 1988; Oberdley, 1988; Hunt et al., 1990; Baynes, 1991; Wolf et al., 1991; Ha and Kim, 1995; Abdel Wahab et al., 1996; Guifliano et al., 1996; Baynes and Thrope, 1999; Auslander et al., 2002). Hyperglycemia-induced oxidative stress has been implicated in the development of diabetic neuropathy in the peripheral (PNS) and central nervous system (CNS) and nephropathy (Oberdley, 1988; Biessels et al., 1994; 2002; Forbes et al., 2003; Biessels et al., 2004).

Streptozotocin (STZ) has broad spectrum antibiotic activity and is often used to induce diabetes mellitus in experimental animals through its toxic effect on pancreatic $\beta$-cells (Ruiz et al., 1994). Besides its antibiotic and diabetogenic properties, STZ is genotoxic in a variety of assays (Ruiz et al., 1994). STZ is a monofunctional nitrosourea derivate that was first isolated from Streptomyces achromogenes (Herr et al., 1967). This toxin has been shown to be involved in the fragmentation of DNA, as well as other deleterious effects by means of the production of ROS (Szkudelski, 2001).

Additionally, free radical scavengers have been shown to protect neurons against a variety of experimental neurodegenerative conditions (Mosmann and Behl, 2002), as well as have been suggested for attenuation the oxidative stress and diabetic state induced by STZ (Agustin et al., 1993; Muñoz et al., 
1993; Montilla et al., 1998). As well, epidemiological and experimental studies have evidenced that moderate consumption of red wine is inversely correlated with the incidence of dementia, oxidative stress and diabetes (Constant, 1997; Tredici et al., 1999; Virgili and Contestabile, 2000; Sabu et al., 2002; Montilla et al., 2004).

We hypothesized that the combination red wine (MontillaMoriles, Cordoaba, Spain) would prevent diabetes-induced changes in cerebral oxidative stress. The present study was designed to look at the effect of red wine in streptozotocininduced oxidative stress in the brain of rats.

\section{Material and Methods}

Drugs and reagements The STZ and reagements were purchased from Sigma Chemical Co. (St. Louis, USA) and were of the highest commercial grade available. The red wine used in the study was donated by the Omeyas Warehouse S. A. (Montilla, Cordoba, Spain).

Animals All animal cares and procedures were in accordance with the European Communities Council Directive of 24 November 1986 (86/609/ECC) and the R.D. 223/1988, and were approved by Bioethics Committee of the University of Cordoba, Spain. Three month-old male Wistar rats weighing between 230- $250 \mathrm{~g}$ at the beginning of the study were purchased from Charles River, Barcelona, Spain. They were subjected to controlled conditions of temperature $\left(20-23^{\circ} \mathrm{C}\right)$, illumination $(12 \mathrm{~h}$ light $/ 12 \mathrm{~h}$ dark cycle, lights on at $08: 00 \mathrm{~h}$ ) and were provided with food (Purina ${ }^{\circledR}$, Barcelona, Spain) and water ad libitum.
Experimental protocols Twenty (20) three month-old Wistar rats were separated into four groups of five animals: Group 1 normal untreated control; Group 2 red wine treated; Group 3 STZ treated; and Group 4 red wine and STZ treated. The STZ treatment was a single i.p. injection of $50 \mathrm{mg} / \mathrm{kg}$ body weight. The red wine treatment was an oral dose $(400 \mathrm{~mL} / 70 \mathrm{~kg}$ body weight/day) administered daily for two weeks prior to the STZ injection and daily for four weeks after the STZ injection. Group 2 received red wine for six weeks.

Rats were fed with Purina ${ }^{\circledR}$ (Barcelona, Spain) rat chow (composition: crude protein $180 \mathrm{~g} / \mathrm{kg}$; fats $32 \mathrm{~g} / \mathrm{kg}$; crude fibre 36 $\mathrm{g} / \mathrm{kg}$; carbohydrate $598 \mathrm{~g} / \mathrm{kg}$ and metabolisable energy $301 \mathrm{kcal} /$ $100 \mathrm{~g})$ throughout the experimental period. After the six week experimental period urine samples were collected one day prior to sacrifice, the animals were sacrificed with blood, brain, and kidney collected. The biochemical parameters determined included: Table 1- plasma: glucose, insulin, BUN, creatinine, total protein, lipid peroxidation, GSH, SOD, and GSH-Px; serum: total cholesterol, triglycerides, HDL-cholesterol and atherogenic index; urine: glucose, albumin and total protein. Table 2- brain lipid peroxidtion, GSH, GSH-Px, SOD and catalase; Table 3- Kidney lipid peroxidation, GSH, GSH-Px, SOD, and catalase.

Evaluation of diabetic state Plasma and urinary glucose was determined using commercial kits (Roche Diagnostics Corporation, Basel, Switzerland) on a Roche-Hitachi 917 autoanalyzer.

Insulin levels in plasma was measured by radioimmunoassay using rat-specific $\left[{ }^{125} \mathrm{I}\right]$-insulin as a tracer kit supplied by CIS Spain (Madrid, Spain).

Table 1. Effects of red wine and STZ on diabetic parameters, lipid profile, urinary excretion and plasma oxidative stress in the rat

\begin{tabular}{|c|c|c|c|c|}
\hline & Control & Red wine & Streptozotocin & $\begin{array}{c}\text { Red wine }+ \\
\text { streptozotocin }\end{array}$ \\
\hline \multicolumn{5}{|l|}{ Plasma } \\
\hline Glucose (mg/dL) & $128 \pm 10$ & $142 \pm 12$ & $443 \pm 47^{\mathrm{a}}$ & $152 \pm 18^{\mathrm{c}}$ \\
\hline Insulin (ng/mL) & $3.2 \pm 0.4$ & $2.9 \pm 0.5$ & $0.32 \pm 0.1^{\mathrm{a}}$ & $2.0 \pm 0.2^{\mathrm{c}}$ \\
\hline BUN (mg/(dL) & $38 \pm 6$ & $40 \pm 3$ & $44 \pm 4$ & $44 \pm 7$ \\
\hline Creatinine (mg/dL) & $0.6 \pm 0.1$ & $0.6 \pm 0.1$ & $0.7 \pm 0.1$ & $0.7 \pm 0.1$ \\
\hline Total protein $(\mathrm{g} / \mathrm{dL})$ & $6.4 \pm 0.2$ & $6.5 \pm 0.2$ & $5.9 \pm 0.8$ & $6.5 \pm 0.1$ \\
\hline Lipid peroxidation products $(\mathrm{nmol} / \mathrm{L})$ & $6.3 \pm 0.6$ & $6.9 \pm 0.7$ & $9.2 \pm 1.1^{\mathrm{a}}$ & $6.1 \pm 0.5^{\mathrm{c}}$ \\
\hline GSH $(\mathrm{nmol} / \mathrm{L})$ & $0.4 \pm 0.1$ & $0.4 \pm 0.1$ & $0.2 \pm 0.1^{\mathrm{a}}$ & $0.3 \pm 0.1^{\mathrm{c}}$ \\
\hline SOD (U/L) & $5.9 \pm 0.3$ & $6.1 \pm 0.6$ & $3.3 \pm 0.3^{\mathrm{a}}$ & $4.2 \pm 0.2^{\mathrm{c}}$ \\
\hline GSH-Px (U/L) & $4.6 \pm 0.6$ & $4.3 \pm 0.6$ & $2.9 \pm 0.6^{\mathrm{a}}$ & $6.5 \pm 0.5^{\mathrm{c}}$ \\
\hline \multicolumn{5}{|l|}{ Serum } \\
\hline Total cholesterol (mg/dL) & $52 \pm 7$ & $52 \pm 5$ & $69 \pm 9^{\mathrm{a}}$ & $60 \pm 5^{b}$ \\
\hline Tryglicerides (mg/dL) & $57 \pm 12$ & $55 \pm 6$ & $56 \pm 17$ & $64 \pm 16$ \\
\hline HDL-C (mg/dL) & $31 \pm 3$ & $34 \pm 2$ & $31 \pm 4$ & $34 \pm 5$ \\
\hline $\mathrm{AI}$ & $0.7 \pm 0.2$ & $0.5 \pm 0.1$ & $1.3 \pm 0.4^{\mathrm{a}}$ & $0.7 \pm 0.3^{\mathrm{c}}$ \\
\hline \multicolumn{5}{|l|}{ Urine } \\
\hline Glucosa (mg/24 h) & $1.9 \pm 1.3$ & $1.2 \pm 2.9$ & $179 \pm 66^{\mathrm{a}}$ & $2.2 \pm 1.1^{\mathrm{c}}$ \\
\hline Albumin (mg/24 h) & $0.1 \pm 0.1$ & $0.1 \pm 0.1$ & $0.4 \pm 0.2^{\mathrm{b}}$ & $0.2 \pm 0.1^{\mathrm{d}}$ \\
\hline Total protein $(\mathrm{g} / 24 \mathrm{~h})$ & $6.6 \pm 1.2$ & $13 \pm 3.7$ & $26 \pm 6.9^{b}$ & $15 \pm 2.5^{\mathrm{d}}$ \\
\hline
\end{tabular}

Values are means $\pm \mathrm{SEM}$ of five rats.

${ }^{\mathrm{a}} p<0.001$ vs control; ${ }^{\mathrm{b}} p<0.05$ vs control; ${ }^{\mathrm{c}} p<0.001$ vs streptozotocin; ${ }^{\mathrm{d}} p<0.05$ vs streptozotocin. 
Table 2. Effect of red wine on changes in lipid peroxidation products levels, reduced glutathione (GSH) content; and superoxide dismutase (SOD), glutathione peroxidase (GSH-Px) and catalase activities brain tissue in rats treated or not with streptozotocin

\begin{tabular}{lllcc}
\hline & Control & Red wine & Streptozotocin & $\begin{array}{c}\text { Red wine }+ \\
\text { streptozotocin }\end{array}$ \\
\hline Lipid peroxidation products (nmol/mg protein) & $8.7 \pm 0.9$ & $8.6 \pm 1.1$ & $15 \pm 1.6^{\mathrm{a}}$ & $7.1 \pm 0.8^{\mathrm{c}}$ \\
GSH (nmol/mg protein) & $0.3 \pm 0.04$ & $0.3 \pm 0.04$ & $0.2 \pm 0.03^{\mathrm{a}}$ & $0.3 \pm 0.04^{\mathrm{c}}$ \\
Catalase $\times$ 10 (U/mg protein) & $0.3 \pm 0.01$ & $0.3 \pm 0.03$ & $0.1 \pm 0.01^{\mathrm{a}}$ & $0.2 \pm 0.02^{\mathrm{c}}$ \\
SOD (U/mg protein) & $9.5 \pm 1.0$ & $9.2 \pm 0.8$ & $6.3 \pm 0.5^{\mathrm{a}}$ & $8.3 \pm 0.6^{\mathrm{c}}$ \\
GSH-Px (U/mg protein) & $3.0 \pm 0.3$ & $2.5 \pm 4$ & $1.4 \pm 0.2^{\mathrm{a}}$ & $2.3 \pm 0.3^{\mathrm{c}}$ \\
\hline
\end{tabular}

Values are means \pm SEM of five rats.

${ }^{\mathrm{a}} p<0.001$ vs control; ${ }^{\mathrm{c}} p<0.001$ vs streptozotocin.

Table 3. Effect of red wine on changes in lipid peroxidation products levels, reduced glutathione (GSH) content; and superoxide dismutase (SOD), glutathione peroxidase (GSH-Px) and catalase activities renal tissue in rats treated or not with streptozotocin

\begin{tabular}{lcccc}
\hline & Control & Red wine & Streptozotocin & $\begin{array}{c}\text { Red wine }+ \\
\text { streptozotocin }\end{array}$ \\
\hline Lipid peroxidation products (nmol/mg protein) & $9.9 \pm 1.4$ & $10 \pm 1.6$ & $16 \pm 1.2^{\mathrm{a}}$ & $12 \pm 1.1^{\mathrm{c}}$ \\
GSH (nmol/mg protein) & $0.6 \pm 0.06$ & $0.6 \pm 0.09$ & $0.3 \pm 0.04^{\mathrm{a}}$ & $0.6 \pm 0.05^{\mathrm{c}}$ \\
Catalase $\times 10$ (U/mg protein) & $0.2 \pm 0.04$ & $0.2 \pm 0.04$ & $0.03 \pm 0.01^{\mathrm{a}}$ & $0.2 \pm 0.03^{\mathrm{c}}$ \\
SOD (U/mg protein) & $14 \pm 0.9$ & $14 \pm 0.7$ & $9.5 \pm 1.0^{\mathrm{a}}$ & $15 \pm 1.3^{\mathrm{c}}$ \\
GSH-Px (U/mg protein) & $2.4 \pm 0.5$ & $1.9 \pm 0.3$ & $1.3 \pm 0.3^{\mathrm{a}}$ & $2.3 \pm 0.3^{\mathrm{c}}$ \\
\hline
\end{tabular}

Values are means $\pm \mathrm{SEM}$ of five rats.

${ }^{\mathrm{a}} p<0.001$ vs control; ${ }^{\mathrm{c}} p<0.001$ vs streptozotocin.

\section{Assessment of oxidative stress}

Estimation of lipid peroxidation products

Brain and kidney were homogenized in ice cold $20 \mathrm{mM}$ Tris-HCl buffer ( $\mathrm{pH}$ 7.4). The homogenates were then centrifuged at 10,000 $\times g$ for $10 \mathrm{~min}$ at $4^{\circ} \mathrm{C}$. The supernatant was collected.

Supernatant and plasma were immediately tested for lipid peroxidation products using the Bioxytech LPO-586 kit (OXIS International, Portland, USA). The kit uses a chromatogenic reagent which reacts with the lipid peroxidation products malondialdehyde and 4-hydroxyalkenals at $45 \pm 1^{\circ} \mathrm{C}$, yielding a stable chromophore with maximum absorbance $586 \mathrm{~nm}$.

Reduced glutathione content

Reduced glutathione (gamma-glutamylcysteinglycine or GSH) content was determined in both brain and renal homogenates and plasma. GSH content was carried out using Bioxytech GSH-400 kit (OXIS International, Portland, USA). The method is based on a chemical reaction which proceeds in two steps, obtaining with GSH a chromophoric thione which has a maximal absorbance wavelength at $400 \mathrm{~nm}$.

Antioxidant enzyme activity

Catalase was measured in the cell cytosol fraction. Catalase was assayed following Aebi (1984), by the rate of decomposition for $\mathrm{H}_{2} \mathrm{O}_{2}$ at $240 \mathrm{~nm}$. The brain and kidney were homogenized in icecold phosphate buffer $\left(6.81 \mathrm{~g} \mathrm{KH}_{2} \mathrm{PO}_{4}\right.$ in water, made up to 1,000 $\mathrm{ml}$ ). The homogenates were then centrifuged at $1,000 \times \mathrm{g}$ for 10 min at room temperature. $\mathrm{H}_{2} \mathrm{O}_{2}(10 \mathrm{mM})$ was used as reagent, with the rate of dismutation of $\mathrm{H}_{2} \mathrm{O}_{2}$ to water and molecular oxygen being proportional to the concentration of catalase and with maximum absorbance at $240 \mathrm{~nm}$.

Total superoxide dismutase (SOD; E.C.: 1.15.1.1) activity was assayed by the Sun et al. technique (1998). Brain and renal tissue was homogenized in ice cold isotonic saline. The homogenates were then centrifuged at $10,000 \times g$ for $10 \mathrm{~min}$ at $4^{\circ} \mathrm{C}$. SOD assay is based on the ability of SOD to inhibit the reduction of nitroblue tetrazolim (NBT) reduction by superoxide generator, with maximum absorbance at $560 \mathrm{~nm}$.

Glutathione peroxidase (GSH-Px; E.C.: 1.11.1.9) activity was evaluated in plasma, and brain and kidney homogenates by the Flohé and Gunzler method (1984). The tissues were homogenized in ice-cold buffer $\left(0.1 \mathrm{M} \mathrm{KH}_{2} \mathrm{PO}_{4} / \mathrm{K}_{2} \mathrm{HPO}_{4}\right.$, pH 7.0, plus $29.2 \mathrm{mg}$ ethylenediaminetetraacetic acid (EDTA) in $100 \mathrm{ml}$ of distilled water and $10.0 \mathrm{mg}$ digitonin in $100 \mathrm{ml}$ of distilled water, final volume, $2,000 \mathrm{ml}$ ) to produce a homogenate. The homogenates were then centrifuged at $10,000 \times \mathrm{g}$ for $10 \mathrm{~min}$ at $4^{\circ} \mathrm{C}$. The glutathione peroxidase assay is based on the oxidation of NADPH to $\mathrm{NAD}^{+}$, catalyzed by a limiting concentration of glutathione reductase, with maximum absorbance at $340 \mathrm{~nm}$.

\section{Protein estimation}

Protein concentration was determined by the Bradford method (1976) using bovine serum albumin as a standard.

Other parameters evaluated Plasma BUN, creatinine, total protein and serum total cholesterol, triglycerides and high-density lipoprotein-cholesterol (HDL-c), as well as urinary levels of total protein and albumin were determined using commercial kits (Roche Diagnostics Corporation, Basel, Switzerland) on a RocheHitachi 917 autoanalyzer. The atherogenic index (AI) was calculated 
as [TC/HDL-c] (Serrano-Martínez et al., 2004).

Statistical analysis Statistical analysis of the data was accomplished by means of the SPSS ${ }^{\circledast}$ statistical software package. The Shapiro-Wilk test did not show a significant departure from normality in the distribution of variance values. To evaluate variations in data, a one-way analysis of variance (one-way ANOVA) was performed followed by Bonferroni correction for multiple comparisons. The level of statistical significance was set at $p<0.05$. All results are expressed as mean \pm S.E.M. Student's $t$-test was used to compare differences between two groups.

\section{Results}

The biochemical parameters indicated that the STZ injection produce diabetic animals with low levels of insulin production, and high levels of plasma glucose, and glucose excretion (Table 1).

Oxidative stress was also induced in the STZ-treated animals with increased lipid peroxidation and decreased GSH, SOD, GSH-Px, and catalase in brain and kidney homogenates and in plasma (Tables 1-3). The determination of nephropathy was determined using BUN, creatinine, and total protein in the serum along with urine glucose, albumin, and protein levels (Table 1). STZ had little effect on the BUN, creatinine and serum protein levels although urine glucose, albumin, and protein were elevated (Table 1).

In all biochemical measurements, red wine alone had no significant effect, but red wine did mitigate all of the STZinduced changes in the measured parameters (Tables 1-3).

\section{Discussion}

STZ-induced diabetes provides a relevant example of endogenous chronic oxidative stress and hyperglycemia. Thus, we evaluated the brain oxidative stress and nephropathy induced by STZ in Wistar rats and examined the potential protective effects of red wine against the changes STZinduced.

Herein we report that: (i) STZ induced a diabetic state characterized by hyperglycemia, glycosuria and decrease in plasma insulin levels; (ii) STZ increased plasma total cholesterol levels and atherogenic index; (iii) STZ triggered a drop in GSH concentration, an increase in lipid peroxidation levels, and reductions in key antioxidative enzymes in the brain, kidney and plasma; (iv) STZ prompted proteinuria and microalbuminuria; (v) the administration of red wine prevented the changes induced by STZ. Likewise, the collected data indicate the important role of the oxidative stress in this experimental model and in the evolution and course of diabetes. And support the hypothesis that STZ induces brain oxidative stress and diabetic state, as well as that red wine has neuroprotective properties and prevents cerebral oxidative stress, diabetes and diabetic nephropathy. The results obtained are in agreement with the reports from Montilla et al.(Muñoz et al., 1993; Montilla et al., 1998; 2004), Ruiz et al. (1994), Hunt et al. (1990; 1993), Baynes (1991), and other researchers (Kakkar et al., 1995; Guigliano et al., 1996; Rauscher et al., 2000), who found that this toxin induced an oxidative stress. We also found a significant correlation among diabetic state, nephropathy and brain oxidative stress. Oxidative stress can both induce lipid peroxidation and oxidative damage leading to cell death and promote the formation of a variety of vasoactive mediators that can affect renal functions. The high degree of oxidative stress in brain and renal tissue coincides with biochemical signs typical of diabetes, such as high levels of glycemia and urinary glucose excretion, as well as dropped in plasma insulin levels. In addition to these data, we observed a significant decrease in plasma insulin levels.

In the current report, the biochemical phenomena triggered by STZ were prevented previously by red wine. These results are compatible with our previous study (Montilla et al., 2004). In this work, we found that treatment with red wine induced decreased levels of glycemia, plasma fructosamine and percentage of glycosylated haemoglobin, while increasing levels of plasma and pancreas insulin (Montilla et al., 2004). Moreover, other studies showed that quercetin, a flavonoid that is widely present in red wines and plants, administration to rats reversed to normality the glucose tolerance test, hepatic glucokinase and hexokinase activities, lipid profile, and the number of pancreatic islets, as well as it decreased the degree of oxidative stress (Vessal et al., 2003). According to Anjaneyulu and Chopra quercetin treatment can play an antioxidative action showing a nephroprotective effect, attenuating diabetic renal damage, probably through its antioxidative action (Anjaneyulu and Chopra, 2004). Furthermore, Watkins' group found that quercetin reversed of compromised antioxidant status in different tissues such as liver, kidney, brain and heart (Sanders et al., 2001; Coldiron et al., 2002). All of these data findings support those found in our study and suggest the protective action of red wine.

Although it was not the main aim of the present study, our results seem to indicate that red wine may affect plasma total cholesterol and atherogenic index. In our study red wine, in combination with STZ dropped total cholesterol and atherogenic index. These data are in agreement with previous reports having shown protective effect of polyphenolic compounds on oxidative stress and hypercholesterolemia (Saini et al., 1994; Magi-Caperyon 2002).

In short, the present results constitute the first in vivo evidence for a neuroprotective role of red wine of the Montilla-Moriles (Cordaba, Spain) in brain oxidative stress in streptozotocin-induced diabetic rats. Thus, red wine reduces the intensity of oxidative stress and the severity of hyperglycemia, while enhancing plasma insulin levels.

Acknowledgments We thank Omeyas warehouse S.A. (Montilla, Cordoba, Spain) for providing the red wine. 


\section{References}

Abdel Wahab, Y. H., O’Harte, F. P., Ratcliff, H., McClenaghan, N. H., Barnett, C. R. and Flatt P. R. (1996) Glycation of insulin in the islets of Langerhans of normal and diabetic animals. Diabetes 45, 1489-1496.

Aebi, H. (1984) Catalase in vitro. Methods Enzymol. 34, 479-500.

Agustin, A. J., Breipohl, W., Boker, T., Lutz, J. and Spitzbas, M. (1993) Increased lipid peroxide levels and myeloperoxidase activity in the vitreous of patients suffering from proliferative diabetic retinpathy. Graefes Arch. Clin. Exp. Ophthalmol. 231, 647-650.

Anjaneyulu, M. and Chopra, K. (2004) Quercetin, an anti-oxidant bioflavonoid, attenuates diabetic nephropathy in rats. Clin. Exp. Pharmacol. Physiol. 31, 244-248.

Auslander, W., Haire-Joshu, D., Houston, C., Rhee, C. W. and Williams, J. H. (2002) A controlled evaluation of staging diatary patterns to reduce the risk of diabetes in AfricanAmerican women. Diabetes Care. 25, 809-814.

Baynes, J. W. (1991) Role of oxidative stress in development of complications in diabetes. Diabetes. 40, 405-412.

Baynes, J. W. and Thorpe, R. (1999) Role of oxidative stress in diabetic complications. A new perspective on an old paradigm. Diabetes. 38, 1-9.

Biessels, G. J., Bravenboer, G. and Gispen, W. H. (2004) Glucose, insulin and the brain: modulation and synaptic plasticity in health and disease: a preface. Eur. J. Pharmacol. 490, 1-4.

Biessels, G. J., Kappelle, A. C., Bravenboer, B., Erkelens, D. W. and Gispen, W. H. (1994) Cerebral function in diabetes mellitus. Diabetologia. 37, 643-650.

Biessels, G. J., van der Heide, L. P., Kamal, A., Bleys, R. L. and Gispen, W. H. (2002) Ageing and diabetes: implications for brain function. Eur. J. Pharmacol. 44, 1-14.

Bradford, M. M. (1976) A rapid and sensitive method for quantitation of microgram quantities of protein utilizing principle of protein-dye binding. Anal. Biochem. 72, 248- 254.

Coldiron, A. D., Sanders, R. A. and Watkins, J. B. (2002) Effects of combined quercetin and Coenzyme $\mathrm{Q}_{10}$ treatment on oxidative stress in normal and diabetic rats. J. Biochem. Mol. Toxicol. 16, 197-202.

Constant, J. (1997) Alcohol, ischemic heart disease and the French paradox. Coron. Artery Dis. 8, 645-649.

Flohé, L. and Gunzler, W. A. (1984) Assays of glutathione peroxidase. Methods Enzymol. 105, 114-121.

Forbes, J. M., Cooper, M. E., Oldfield, M. D. and Thomas, M. C. (2003) Role of advanced glycation end products in diabetic nephropathy. J. Am. Soc. Nephrol. 14, 254-258.

Gispen, W. H. and Biessels, G. J. (2000) Cognition and synaptic plasticity in diabetes mellitus. Trends Neurosci. 23, 542-549.

Giugliano, D., Ceriello, A. and Paolisso, G. (1996) Oxidative stress and diabetic vascular complications. Diabetes Care. 19, 257-267.

Ha, H. and Kim, K. H. (1995) Role of oxidative stress in the development of diabetic nephropathy. Kidney Int. 48, 18-21.

Herr, R. R., Jahnke, A. D. and Argoudelis, A. D. (1967) The structure of streptozotocin. J. Am. Chem. Soc. 89, 4808-4809.

Hunt, J. V., Bottoms, M. A. and Mitchinson, M. J. (1993) Oxidative alterations in the experimental glycation model of diabetes mellitus are due to protein-glucose adduct oxidation: Some fundamental differences in proposed mechanism of glucose oxidation and oxidant production. Biochem. J. 291, 259-262.

Hunt, J. V., Smith, C. and Wolff, S. P. (1990) Autoxidative glycosilation and possible involvement of peroxides and free radicals in LDL modification by glucose. Diabetes. 39, 14201424.

Hyslop, P. A., Hinshwa, D. B. and Halsey, W. H. Jr. (1988) Mechanism of oxidant-mediated cell injury: the glycolytic and mitochondrial pathways of ADP phosphorylation are major intracellular targets inactivated by hydrogen peroxide. J. Biol. Chem. 263, 1665-1675.

Kakkar, R., Kalra, J. and Mantha, S. V. (1995) Prasad K. Lipid peroxidtion and activity of antioxidant enzymes in diabetic rats. Mol. Cell Biochem. 151, 113-119.

Maggi-Caperyon, M. F., Cases, J., Badia, E., Cristol, J. P., Rouanet, J. M., Besancon, P., Leger, C. L. and Descomps, B. (2002) A diet high in cholesterol and deficient in vitamin E induces peroxidtion but does not enhance antioxidant enzyme expression in rat liver. J. Nutr. Biochem. 13, 296-301.

McCall, A. L. (1992) The impact of diabetes on the CNS. Diabetes. 41, 557-570.

Montilla, P., Barcos, M., Muñoz, M. C., Muñoz-Castañeda, J. R., Bujalance, I. and Túnez, I. (2004) Protective effect of MontillaMoriles appellation red wine on oxidative stress induced by streptozotocin in the rat. J. Nutr. Biohcem. 15, 688-693.

Montilla, P., Vargas, J., Túnez, I., Muñoz, M. C., Valdelvira, M. E. and Cabrera, E. (1998) Oxidative stress in diabetic rats induced by streptozotocin: protective effects of melatonin. J. Pineal Res. 25, 94-100.

Mosmann, B. and Behl, C. (2002) Antioxidants as treatment for neurodegenerative disorders. Expert Opin. Investig. Drugs. 11, 1407-1435.

Muñoz, M. C., Túnez, I., Porras, T. and Montilla, P. (1993) Curso evolutivo de la glucose, fructosamina y lipoperóxidos plasmáticos en ratas diabéticas por estreptozotocina. Efectos de la vitamina E. Clin. Invest. Arterioscler. 5, 114-117.

Oberdley, L. W. (1988) Free radicals and diabetes. Free Radic. Biol. Med. 5, 113-124.

Rauscher, F. M., Sanders, R. A., Watkins, J. B. (2000) Effects of new antioxidant compounds PNU-104067F and PNU-74389G on antioxidant defense in normal and diabetic rats. J. Biochem. Mol. Toxicol. 14, 189-194.

Ruiz, C., Alegria, A., Barbera, R., Farre, R. and Lagarda, M. J. (1994) Lipid peroxidation and antioxidant enzyme activities in patient with type-I diabetes mellitus. Scand. J. Clin. Lab. Invest. 59, 99-105.

Saini, H. K., Arneja, A. S. and Dhalla, N. S. (2004) Role of cholesterol in cardiovascular dysfunction. Can. J. Cardiol. 20, 333-346.

Sanders, R. A., Rauscher, F. M. and Watkins, J. B. (2001) Effect of quercetin on antioxidant defense in streptozotocin-induced diabetic rats. J. Biochem. Mol. Toxicol. 15, 143-149.

Sabu, M. C., Smith, K. and Kuttan, R. (2002) Anti-ciabetic activity of green tea poolyphenols and their role in reducing oxidative stress in experimental diabetes. J. Ethnopharmacol. 83, 109-116.

Serrano-Martínez, M., Martínez-Losada, E., Prado-Santamaría, M., Brugarola-Brufau, C., Fenández-Jarne, E. and MartínezGonzález, M. A. (2004) To what extent are the effects of diet on coronary Herat disease lipid-mediated? Int. J. Cardiol. 95, 
35-38.

Sun, Y., Oberley, L. W. and Li, Y. (1998) A simple method for clinical assay of superoxide dismutase. Clin. Chem. 34, 479500 .

Szkudelski, T. (2001) The mechanism of alloxan and streptozotocin action in b-cells of the rat pancreas. Physiol. Res. 50, 536-546.

Tredici, G., Miloso, M., Nicolini, G., Galbiati, S., Cavalletti, G. and Bertelli, A. (1999) Resveratrol, map kinases and neuronal cells: might wine be a neuroprotectant? Drugs Exp. Clin. Res. 25, 673-680.
Virgili, M. and Contestabile, A. (2000) Partial neuroprotection of in vivo excitotoxic brain damage by chronic administration of the red wine antioxidant agent, trans-reveratrol in rats. Neurosci. Lett. 281, 123-126.

Vessal, M., Hemmati, M. and Vasei, M. (2003) Antidiabetic effects of quercetin in streptozotocin-induced diabetic rats. Comp. Biochem. Physiol. C. 135, 357-364.

Wolf, S. P., Jiang, J. Y. and Hunt, J. V. (1991) Protein glycation and oxidative stress in diabetes mellitus and ageing. Free Radic. Biol. Med. 10, 339-352. 